Sains Malaysiana 49(5)(2020): 1021-1036

http://dx.doi.org/10.17576/jsm-2020-4905-07

\title{
Health Literacy Research in Malaysia: A Scoping Review
}

(Penyelidikan Literasi Kesihatan di Malaysia: Suatu Ulasan Penskopan)

\author{
Adina Abdullah, Liew Su MaY*, Hani Syahida Salim, Ng Chirk Jenn \& Karuthan Chinna
}

\begin{abstract}
Research on health literacy is expanding worldwide. Health literacy has been recognised as a critical determinant of health at the 2016 Shanghai Declaration. Little is known about health literacy research in Malaysia. This scoping review aims to identify and summarise published studies on health literacy in Malaysia. PubMed, Scopus and the Malaysian Medical Repository (MyMedR) databases were searched for published work by Malaysian researchers. Searches were conducted up to November 2019. The search terms used are related to 'health literacy' and 'Malaysia'. Studies included were those involving Malaysian citizens and reporting on various aspects of health literacy. Studies were reviewed by two independent reviewers to determine their eligibility. Data extraction for the year of publication, name of authors, geographical location, research focus, and summary of findings from the full-text articles was carried out independently and any disagreement was resolved by consensus. A total of 29 articles were included with the earliest article published in 1985. Fifteen of the articles are on general health literacy, four on medication literacy, five on mental health literacy, three on media and e-health literacy and four on oral health literacy. Four articles are qualitative studies and the rest are quantitative studies. A few of the studies used validated health literacy tools such as Newest Vital Signs and HLS-EU-Q47. Therefore, we can conclude that there are only a limited number of articles published in the field of health literacy in Malaysia. Future work using validated international tools to allow comparison of the findings should be considered.
\end{abstract}

Keywords: Health literacy; Malaysia; medication literacy; mental health literacy

ABSTRAK

Penyelidikan literasi kesihatan semakin mendapat perhatian di seluruh dunia. Literasi kesihatan telah diiktiraf sebagai penentu kesihatan yang kritikal pada Deklarasi Shanghai 2016. Amat sedikit yang diketahui tentang penyelidikan literasi kesihatan di Malaysia. Kajian ini bertujuan untuk mengenal pasti dan meringkaskan terbitan kajian tentang literasi kesihatan di Malaysia. Pangkalan data PubMed, Scopus dan Malaysian Medical Repository (MyMedR) digunakan sebagai sumber untuk kajian yang diterbitkan oleh penyelidik Malaysia. Carian telah dijalankan sehingga November 2019. Terma carian yang digunakan berkaitan adalah 'literasi kesihatan' dan 'Malaysia'. Kajian yang terlibat adalah dalam kalangan rakyat Malaysia tentang pelbagai aspek literasi kesihatan. Kajian dikaji semula oleh dua pengulas bebas untuk menentukan kelayakan mereka. Pengekstrakan data melibatkan tahun penerbitan, nama pengarang, lokasi geografi, fokus penyelidikan dan ringkasan penemuan daripada artikel teks penuh dijalankan secara bebas dan sebarang perselisihan diselesaikan melalui persetujuan. Sebanyak 29 artikel disertakan dengan artikel terawal yang diterbitkan pada tahun 1985. Lima belas artikel itu adalah tentang literasi kesihatan umum dengan empat literasi perubatan, lima literasi kesihatan mental, tiga di media dan literasi e-kesihatan dan empat literasi kesihatan mulut. Empat artikel adalah kajian kualitatif dan selebihnya adalah kajian kuantitatif. Beberapa kajian menggunakan alat literasi kesihatan yang disahkan seperti Newest Vital Signs dan HLS-EU-Q47. Oleh itu, secara kesimpulan, terdapat hanya sedikit artikel yang diterbitkan dalam bidang literasi kesihatan di Malaysia. Pada masa hadapan penggunaan alat antarabangsa yang disahkan untuk membolehkan perbandingan penemuan harus dipertimbangkan.

Kata kunci: Celik kesihatan mental; literasi kesihatan; literasi perubatan; Malaysia

\section{INTRODUCTION}

Health literacy plays an important role in empowering citizens to make healthy choices and participate in their healthcare. Health literacy is often defined as people's ability to access, understand, appraise and apply health information to make judgement and decisions concerning their health (Nielsen-bohlman et al. 2004). Population studies showed that nearly half of European adults have less than sufficient health literacy and only $12 \%$ of American adults have proficient health literacy. People with limited health literacy are less likely to use preventive services (Scott et al. 2002) to seek help when they are sick, (Bennett et al. 1998), and more likely to overuse healthcare services with higher rate of hospitalisation and use of 
emergency services (Baker et al. 2002, 1998; Gordon et al. 2002). As a result, this leads to higher healthcare costs (Howard et al. 2005). Limited health literacy in patients with non-communicable diseases such as high blood pressure (Williams et al. 1998), diabetes (Schillinger et al. 2003, 2002; Williams et al. 1998a)or HIV/AIDS (Kalichman \& Rompa 2000; Kalichman et al. 2000) have less knowledge of their illnesses and how to manage them.

There is an increasing number of health literacy studies published each year (Kondilis et al. 2008). Health literacy research published in the United States and Europe (EU) had been used to draw up documents which shaped health system policy and law. In the United States, the first of these documents is 'Health Literacy: A Prescription to End Confusion' which was published by the Institute of Medicine in 2004 and led to the formation of the Plain Writing Act of 2010 (Nielsen-bohlman et al. 2004). In recent years, several EU Member States such as Germany, Ireland, Scotland, Austria, and Switzerland published their own policy documents relating to health literacy (Heijmans et al. 2014).

Recently, at the Ninth Global Conference on Health Promotion in Shanghai, member countries endorsed the Shanghai declaration (which recognised health literacy as a critical determinant of health) and made a commitment to invest in its development (World Health Organization 2017). Malaysia is one of the signatories of this declaration, committed to develop, implement and monitor intersectoral, national and local strategies for strengthening health literacy in all populations and in all educational settings. Unfortunately, little is known about the studies on health literacy done in our country, Malaysia. Results from health literacy research done in other countries are not transferable to our local setting. Health literacy is a social construct and greatly influenced by culture (Shaw et al. 2009). Culture gives significance to health information and can shape an individual's perception and definition of health and illness. This, in turn, influences the understanding of health literacy in different countries and settings.

So far, findings on the levels of population health literacy are alarming. In 2015, the National Health and Morbidity survey measured the population health literacy for the first time. It was found that only $6.6 \%$ of Malaysian adults have adequate health literacy (Institute for Public Health (IPH) 2015). This finding warrants further examination of research already done in the area of health literacy in Malaysia. This scoping review aims to identify and synthesise published health literacy research done in Malaysia thus far. It will be the first review to summarise published work in this area and to provide recommendations for future research.

\section{MATERIALS AND METHODS}

We searched databases archiving published work by Malaysian researchers, the PubMed, Scopus and the Malaysian Medical Repository (MyMedR) databases.
MyMedR is an open-access database of published Malaysian health and biomedical research. The materials are imported from PubMed and MyJurnal. The search terms used for health literacy were ('health literacy' OR 'health literate' OR 'medical literacy') OR 'sexual health literacy') OR 'mental health literacy') OR ('health'[Title/Abstract] AND 'literacy'[Title/ Abstract])) OR 'numeracy') OR 'health literacy'[MeSH Terms] and Malaysia (all fields). These were restricted to English and Malay language. The searches were conducted up to November 2019. Two papers were found by tracking authors known for their research on health literacy in Malaysia.

Two unanimous reviewers assessed the articles to see if they fulfil the inclusion criteria. The inclusion criteria were as follow: the study was conducted in Malaysia, on Malaysian populations, and the study reported on health literacy. Any disagreement was resolved by consensus. Definitions of health literacy had gone through many evolutions; the one used in this review was "the capacity of individuals to obtain, process, and understand basic health information and services needed to make appropriate health decisions" (Nielsen-bohlman et al. 2004). Therefore, only studies that measured patients' capability to obtain, process and understand health information will be included. Studies focused solely on measuring disease knowledge were excluded. Only original studies published in full manuscript were included.

Full-text articles were obtained for those that fulfilled the inclusion criteria. Duplicates were excluded. Reviewers carefully read the articles and extracted relevant information. Study quality was not assessed as the focus of this review was to know the breadth of health literacy research in Malaysia rather than excluding studies based on their quality. The reason for this was to be as inclusive as possible. Data on the year of publication, authors, state in Malaysia where the research was conducted, area of health literacy tackled, and summary of findings were extracted.

\section{RESULTS}

\section{STUDY SELECTION AND CHARACTERISTICS}

Figure 1 shows the flow chart of the article selection process. The search resulted in 203 articles and another 2 articles were found through authors' tracking. We assessed 126 articles for eligibility after excluding 79 duplicates. Only 29 fulfilled the inclusion criteria and were included in this review. These studies could be grouped into five main areas of health literacy, mainly: general health literacy, mental health literacy, medication literacy, media and e-health literacy, and oral health literacy. Articles from the same area will be discussed together. 


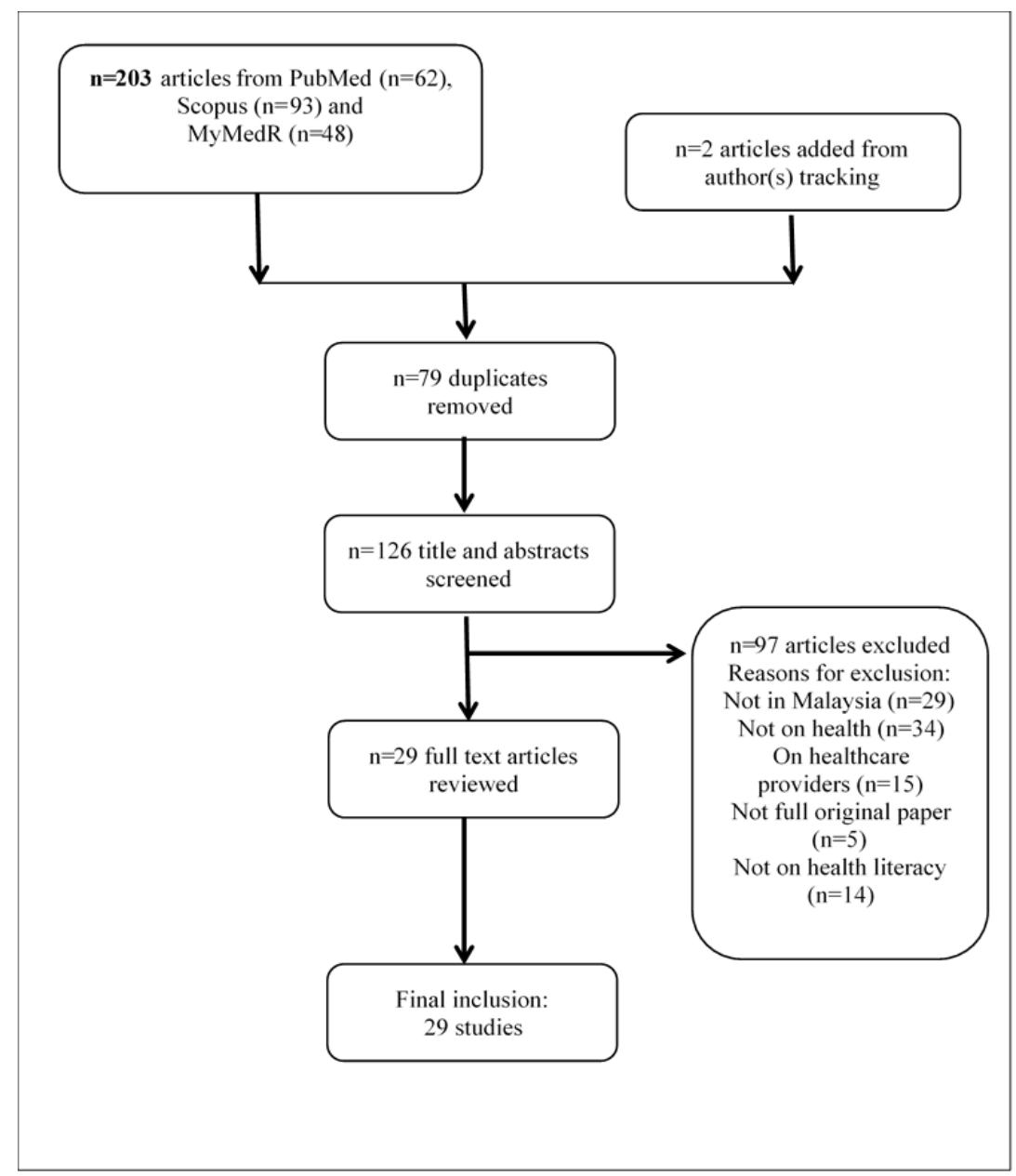

FIGURE 1. Flow chart of study selection

\section{DATA EXTRACTION AND SYNTHESIS}

Table 1 summarised articles that were reviewed. Four studies used a qualitative study design, one used a mixed methods design and the rest employed a quantitative study design. Table 2 provides information on health literacy tools used in the quantitative studies included in this review. The first article we identified was published in 1985 . However, majority of the articles were published after 2010. Most studies were conducted in the states of Peninsular Malaysia $(\mathrm{n}=27)$ and in Klang Valley, namely the urban states of Kuala Lumpur and Selangor $(n=12)$. Two papers published data from multi-country collaboration studies, allowing direct comparison of health literacy findings in Malaysia to that in other countries.

TABLE 1 . Summary of included studies

\begin{tabular}{|c|c|c|c|c|c|}
\hline Author(s) & Location & Main aim & Study design & Setting & Results \\
\hline \multicolumn{6}{|c|}{ General Health Literacy } \\
\hline (Bee 1985) & Sarawak & NR & $\begin{array}{l}\text { Cross- } \\
\text { sectional } \\
\text { study }\end{array}$ & Community & $\begin{array}{l}\text { The study population experienced a } \\
\text { moderate prevalence of morbidity, the } \\
\text { bulk of which were mild conditions easily } \\
\text { treated by primary health care workers. } \\
\text { The interviews on health literacy also } \\
\text { show large gaps in the knowledge of the } \\
\text { respondents with regards to the causation, } \\
\text { spread and prevention of diseases. Another } \\
\text { important finding stemmed from the study } \\
\text { is the possible deleterious effects of food } \\
\text { taboos on the diets of women during the } \\
\text { post-partum period. }\end{array}$ \\
\hline
\end{tabular}


(Khan et al. Pulau 2010) Pinang to evaluate and compare the knowledge, attitude and perception about breast cancer among the students from different ethnic groups
(Norrafizah Pahang et al. 2016) to investigate the impact of sociodemographic factors on the acquisition of health information on NonCommunicable Diseases (NCDs) among Malaysian adults
to determine the use of the Newest Vital Sign (NVS) in the Malay language as a tool to measure the level of health literacy among adults in the rural population in Malaysia

\begin{tabular}{|c|c|c|}
\hline $\begin{array}{l}\text { (Skau et al. } \\
\text { 2016) }\end{array}$ & $\begin{array}{l}\text { Negeri } \\
\text { Sembilan }\end{array}$ & $\begin{array}{l}\text { to evaluate } \\
\text { the efficacy } \\
\text { of a complex } \\
\text { behavioural } \\
\text { change } \\
\text { intervention } \\
\text { combining } \\
\text { behaviour change } \\
\text { counselling } \\
\text { provided by } \\
\text { community } \\
\text { health promoters } \\
\text { (CHPs) and } \\
\text { utilisation of an } \\
\text { E-health platform } \\
\text { to enhance } \\
\text { women's } \\
\text { health prior to } \\
\text { pregnancy }\end{array}$ \\
\hline
\end{tabular}

Qualitative Malaysian public study university

Crosssectional study

Public area including university, shopping malls, offices and cafes,

\section{Cross- \\ Community} sectional study

This study protocol describes the first community-based randomised controlled trial, to examine the efficacy of a complex intervention in improving the prepregnancy health of young Malaysian women and their spouses. Results from this trial will contribute to improved policy and practices regarding complex behavioural change interventions to prevent diabetes in the pre-conception period in Malaysia and other low- and middle-income country settings.
The findings demonstrate that the Thai terms of diagnosis, mammography and physical examination were recommended by a majority of the students. Surgery options to treat breast cancer. Thai students had good knowledge about the symptoms of breast cancer. However, the knowledge level on the diagnosis of breast cancer was the best among the Malays and the Arabs.

The results suggest that old individuals, disease and with history of serious family information on to acquire poor health Malays, Chinese, males and those of low education are $8.76 \%, 6.22 \%, 2.94 \%$ and $21.62 \%$ more likely to acquire poor health information on NCDs than others.

The study showed that, of the 111 questionnaire within three minutes. Seven $(20.6 \%)$ adults were of adequate literacy having the ability to answer a minimum of four questions correctly within three minutes given. Meanwhile, $17(50.0 \%)$ adults were of limited possible literacy and $10(29.4 \%)$ were of the limited likely group. 
(Azreena et Selangor al. 2016)

\section{(Hamzah Malaysia,}

et al. 2016) multi-states

$\begin{array}{ll} & \\ & \\ \text { (Chuen et } & \text { States in } \\ \text { al. 2016) } & \text { Malaysia } \\ & \\ & \\ & \\ & \\ \text { (Duong et } & \text { Kuala } \\ \text { al. 2017) } & \text { Lumpur, } \\ & \text { Selangor, } \\ & \text { Perak }\end{array}$

(Shahrir et Klang al. 2018) Valley to determine the

level of health

literacy and its

associated factors

among type 2

diabetes mellitus

patients attending

a government

health clinic
Cross-

sectional

Government health

study

clinic

.




\begin{tabular}{|c|c|c|c|c|c|}
\hline $\begin{array}{l}\text { (Hagger et } \\
\text { al. 2018) }\end{array}$ & $\begin{array}{l}\text { Malaysia, } \\
\text { multi } \\
\text { ountry }\end{array}$ & $\begin{array}{l}\text { to examine } \\
\text { the prevalence } \\
\text { and predictors } \\
\text { of HL in FH } \\
\text { patients attending } \\
\text { clinics in seven } \\
\text { countries }\end{array}$ & $\begin{array}{l}\text { Cross- } \\
\text { sectional } \\
\text { study }\end{array}$ & $\begin{array}{l}\text { Familial } \\
\text { hypercholesterolemia } \\
\text { (FH) clinics }\end{array}$ & $\begin{array}{l}\text { Inadequate HL was lowest in the UK } \\
(7.0 \%) \text {, Australia }(10.0 \%) \text {, Hong Kong } \\
(15.7 \%) \text {, and Taiwan }(18.0 \%) \text { samples, } \\
\text { with higher rates in Brazil }(22.0 \%) \text {, } \\
\text { Malaysia }(25.0 \%) \text {, and China }(37.0 \%) \\
\text { samples. Income was an independent } \\
\text { predictor of HL levels, accounting for } \\
\text { effects of age. HL was also independently } \\
\text { related to China national group } \\
\text { membership. }\end{array}$ \\
\hline
\end{tabular}

(Hamzah et Klang

al. 2018) Valley to research the

Cross-

influence of sectional parental and peer attachment on the health literacy of adolescents

Secondary School study

to determine the change of HL scores and to investigate the difference of intervention outcomes at the weight loss (WL) intervention and WL maintenance phase between the HL groups
(Froze et Sarawak al. 2019)
to identify the
determinants of health literacy and healthy lifestyle practice against metabolic syndrome among the multi-ethnic group of Sarawak based on health literacy skills framework

RCT
Cross- NR sectional study
Low-cost flat

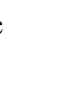

.




$\begin{array}{llll}\text { (Duong } & \text { Kuala } & \text { to develop } & \text { Validation } \\ \text { et al. } & \text { Lumpur, } & \text { and validate } & \text { NR } \\ \text { 2019)024 } & \text { Selangor, } & \text { a short-form } & \\ & \text { Perak } & \text { HL instrument } \\ \text { derived from } & \\ & & \\ & & \text { European } & \\ & \text { Health Literacy } \\ & \text { Questionnaire } \\ & \text { (HLS-EU-Q47) }\end{array}$

The HLS-SF 12 was demonstrated to have adequate psychometric properties, including high reliability (Cronbach's alpha $=.85$ ), good criterion-related validity, a moderate and high level of item-scale convergent validity, no floor or ceiling effect, and good model-datafit throughout the populations in these countries.

Medication Literacy

(Chan et al. Kedah

to explore the

Cross-

A government-

Health literacy was measured using

2015)

health literacy

sectional

funded tertiary

of the Malaysian

study

hospital

caregivers

who received

medications for

their children

by using a

validated tool.

Besides, the

influences of

their health

literacy on

comprehension

of information on

medication labels

were examined

(Tan et al. Pulau

2015) Pinang

to evaluate

Malaysian

consumers'

practices,

perceptions and

understanding

regarding the use

of acetaminophen

\section{Qualitative University based} study

\section{clinics and two}

selected community

pharmacies.
Consumers have a positive attitude towards the popularity, safety and efficacy of acetaminophen. Consumers predominantly used acetaminophen for pain and fever. Some consumers tend to increase the frequency and dosage of acetaminophen consumption if their condition persisted. Consumers have difficulty recognising generic acetaminophen-containing products available in the market. Health literacy investigations found that consumers lack knowledge of the correct dosing regimen for acetaminophen in adults and children. Consumers are not aware of the precautions and toxicities of acetaminophen. To increase awareness of acetaminophen poisoning in Malaysia, educational tools regarding the proper use of acetaminophen are needed from the Ministry of Health and policy-makers. 
(Zulkifli et Klang

al. 2016) Valley

(Nazatul Negeri

Yusrina et Sembilan

al. 2017)
Why the public

is still buying

unregistered

drugs in

Malaysia

although there

are awareness

campaigns

throughout

Malaysia?

How are the

performances

of the current

awareness and

educational

programmes?

How can these

awareness and

educational

programmes

be improved

and be targeted

to reduce

unregistered

drugs purchases

amongst the

public?

to study the

predictors of

health literacy

on childhood

immunisation

among antenatal

women
Mixed- NR

method

Most of the participants believed that the best tools for educating people about the dangers of unregistered drugs are television, Facebook (social media) and the internet. The majority of participants, $75 \%(n=12)$ also believed that raising awareness about the bad impact of unregistered drugs may discourage public purchase of unregistered drugs. The majority of pharmacists believed that health literacy is the most important aspect of developing a good sense of consumer understanding of unregistered drugs in consumers. The pharmacists believed that low health literacy would influence the public to purchase unregistered drugs.

Cross-
sectional
study

$81.2 \%$ of antenatal mothers have inadequate health literacy. The predictors were maternal education $(\mathrm{AOR}=2.608$, $95 \%$ CI 1.477-4.604), parity $(\mathrm{AOR}=1.067$, 95\% CI 1.103-3.876), residential area $(\mathrm{AOR}=2.344,95 \%$ CI 1.184-4.641) and utilisation of government hospital $(\mathrm{AOR}=$ $2.344,95 \%$ CI 1.184-4.641).

\begin{tabular}{|c|c|c|c|c|}
\hline \multicolumn{5}{|c|}{ Mental Health Literacy } \\
\hline $\begin{array}{l}\text { (Khan et al. } \\
2010 \text { ) }\end{array}$ & $\begin{array}{l}\text { Pulau } \\
\text { Pinang }\end{array}$ & $\begin{array}{l}\text { to determine } \\
\text { the level of } \\
\text { knowledge } \\
\text { of depression } \\
\text { among students } \\
\text { at a Malaysian } \\
\text { university }\end{array}$ & $\begin{array}{l}\text { Cross- } \\
\text { sectional } \\
\text { study }\end{array}$ & Public university \\
\hline
\end{tabular}

\author{
Overall, the findings demonstrate a \\ moderate level of knowledge among \\ students. Of the different cultural groups, \\ the findings showed that Chinese students \\ have the best knowledge of the symptoms \\ of depression, followed by the Malays and \\ Indians. Regarding beliefs on the causes \\ of depression, the majority identified \\ educational issues such as failures in \\ achievement and education-related \\ problems (such as examinations and \\ projects) as the major cause of depression. \\ However, the death of a loved one, \\ relationship problems and home/family \\ disharmony were found to be perceived \\ as significant causes of depression. The \\ findings showed only a cursory knowledge \\ of the medications used in the treatment \\ of depression among respondents. The \\ majority recommended alternative \\ treatments, such as yoga, massage and \\ traditional medicines. Ethnic background \\ and religion have been observed as \\ underpinning the belief in traditional ways \\ of curing depression, such as yoga and \\ meditation.
}


(Loo et al. Malaysia, 2012)

multi
country

(Mohamad Northern

et al. 2012) states

\section{(Siti}

Fatimah et

al. 2016)

Selangor to examine the

ability of

British,

Malaysian and

Hong Kong

participants

to identify

nine different

psychiatric

vignettes. The

second aim

of the study

is to compare

treatment

preferences

in the form of

recommended

help for the

person in the

vignette

to identify

caregivers'

mental health

literacy in

Malaysia

to investigate the

RCT

effectiveness of a

4-week

Web-based

sychoeducational

intervention

program for

depressive and

anxiety

symptoms

in the community

of Selangor,

Malaysia
Cross-

sectional

study

Qualitative

study

$\begin{array}{llll}\begin{array}{ll}\text { (Ibrahim et } \\ \text { al. 2019) }\end{array} & \begin{array}{l}\text { Malaysia, } \\ \text { multi-states }\end{array} & \begin{array}{l}\text { to examine the } \\ \text { factors associated } \\ \text { with a mental } \\ \text { help-seeking } \\ \text { attitude among } \\ \text { students from }\end{array} & \begin{array}{l}\text { Cross- } \\ \text { sectional } \\ \text { study }\end{array} \\ & & \\ & & \\ & & \text { bracket }\end{array}$

Community

The British were the most adept at correctly identifying the cases of mental disorders in the vignettes followed by the Hong Kong Chinese and Malaysians. Overall, depression cases were the best identified and social phobia was the least identified. In terms of help recommendation, a higher percentage of British participants endorsed professional help as useful for the person in the vignette compared to Hong Kong and Malaysian participants.
Community clinics

Community

Most of the caregivers have some understanding of their relatives' mental illnesses. More than half of the participants found that the doctors were considered as their primary source of information about mental health. Most of the caregivers used religious and traditional coping mechanisms in their help-seeking processes. Each ethnic group had its own strong cultural beliefs about mental illness.

The program aims to address the predictors that contribute to depression and anxiety in our community. This brief Web-based program will enable the community to use easy, user-friendly, valid, and reliable tools for assessing their mental health status. Second, the availability of the program in both English and Malay languages is an additional plus point. Participants can choose their preferred languages to complete the sessions. Third, the assessments are available in both languages and have been validated in our population. Fourth, the intervention program was designed to be as brief as possible to increase the acceptability of the program versus other lengthier interventions, which could further increase the dropout rates.

Secondary school and University
Mental help-seeking attitude had a significant relationship with self-stigma on seeking help $(\mathrm{r}=-.258, \mathrm{p}<.001)$, general help-seeking attitude $(\mathrm{r}=.156, \mathrm{p}=.027)$, and age $(\mathrm{r}=.187, \mathrm{p}<.001)$. However, the strongest predictor for mental help-seeking attitude was self-stigma on seeking help ( $\mathrm{F}$ $(2,199)=8.207, \mathrm{p}<.001$ with R2 of .076). University students had better depression literacy and lower levels of self-stigma and negative beliefs toward mental illness compared to secondary school students. 
Media and e-Health literacy

\begin{tabular}{|c|c|c|c|c|c|}
\hline $\begin{array}{l}\text { (Zalma et } \\
\text { al. 2015) }\end{array}$ & Selangor & $\begin{array}{l}\text { to determine } \\
\text { the reliability } \\
\text { and validity of } \\
\text { television food } \\
\text { advertising }\end{array}$ & $\begin{array}{l}\text { Validation } \\
\text { study }\end{array}$ & Primary school & $\begin{array}{l}\text { The questionnaire on television food } \\
\text { advertising is reliable and valid to asse } \\
\text { the effect of media literacy education } \\
\text { on television food advertising on } \\
\text { schoolchildren. }\end{array}$ \\
\hline
\end{tabular}

$\begin{array}{ll}\text { (Mohamad } & \text { Klang } \\ \text { et al. 2015) } & \text { Valley }\end{array}$

(Yilma et NR

al. 2019) to examine the

media's role in

health literacy

and mothers'

ability to access,

understand,

appraise

and apply

information on

children growing

up milk

\author{
Qualitative NR \\ study
}

Media could contribute towards mothers health literacy, particularly through the information portrayed. However, the access, level of understanding and judgement of this information do not guarantee their health behaviours.

$\begin{array}{lll}\text { to assess the } & \text { Cross- } & \text { University campus } \\ \text { search behaviour } & \text { sectional } & \\ \text { of consumers } & \text { study } & \\ \text { and identify } & \text { xperimental } & \\ \text { contextual factors } & \text { design) } \\ \text { affecting health } & \\ \text { information } & \\ \text { searching on the } & \\ \text { Web } & \end{array}$

Frequent health information seeking led to more queries and long query length. English as a mother tongue and being healthy contributed to long query length. Queries with spelling errors and those formulated outside task descriptions were found to be ineffective.

Oral health literacy

\begin{tabular}{|c|c|c|c|c|c|}
\hline $\begin{array}{l}\text { (Fabillah et } \\
\text { al. 2015) }\end{array}$ & $\begin{array}{l}\text { Kuala } \\
\text { Terengganu }\end{array}$ & $\begin{array}{l}\text { to assess the oral } \\
\text { health literacy } \\
\text { among carers } \\
\text { of special needs } \\
\text { children }\end{array}$ & $\begin{array}{l}\text { Cross- } \\
\text { sectional } \\
\text { study }\end{array}$ & $\begin{array}{l}\text { Community- Based } \\
\text { Rehabilitation } \\
\text { Centres }\end{array}$ & $\begin{array}{l}\text { Majority of the participants had 'marginal' } \\
\text { and 'adequate' OHL level of } 32.5 \% \text { and } \\
52.5 \% \text {, respectively. Only four }(10 \%) \\
\text { participants had 'inadequate' OHL } \\
\text { level. The 'reading comprehension' and } \\
\text { 'numeracy' sections' mean scores were } \\
37.54 \text { (95\% CI } 35.7-39.4) \text { and } 38.17 \\
\text { (95\% CI } 34.8-41.6) \text {. The total OHL } \\
\text { mean score was } 75.7 \text { (95\% CI } 71.2-80.2) \text {. }\end{array}$ \\
\hline $\begin{array}{l}\text { (Ismail et } \\
\text { al. 2018) }\end{array}$ & Pahang & $\begin{array}{l}\text { to assess the } \\
\text { parental Oral } \\
\text { Health Literacy } \\
\text { (OHL) and its } \\
\text { association } \\
\text { with the oral } \\
\text { health status } \\
\text { of preschool } \\
\text { children }\end{array}$ & $\begin{array}{l}\text { Cross- } \\
\text { sectional } \\
\text { study }\end{array}$ & Preschool & $\begin{array}{l}\text { The negative correlation between parental } \\
\text { OHL and the oral health status of children } \\
\text { indicates that when parental OHL level } \\
\text { increases, the total dental caries } \\
\text { experience (dmft) and oral hygiene status } \\
\text { (visible plaque index: VPI) decreases } \\
\text { ( }<<0.05) \text {. Lower dmft and VPI scores were } \\
\text { also observed among preschool children } \\
\text { of parents in the group with high parental } \\
\text { OHL }(p<0.05) \text {. }\end{array}$ \\
\hline
\end{tabular}


(Rani et al. Kuala 2019) to evaluate

the oral

health literacy

level among

adolescents,

prior to and

after the oral

health education

program using

visual oral health

literacy tool
Cross- Secondary schools

sectional

study

At the baseline, the students had a low

visual oral health literacy score for both gingival, and tooth scores with the gingival score being significantly lower. The upper tooth and gingival scores were higher than the lower tooth and gingival scores. Comparison of scores before and after oral health education showed that both the tooth and gingival scores improved significantly. Visual oral health literacy tool allows evaluation of students' oral health literacy both visually and quantitatively.

$\mathrm{NR}=$ Not reported

TABLE 2. Health literacy tools used in Malaysia

\begin{tabular}{|c|c|c|c|c|c|c|}
\hline Measure & Type of Measure & $\begin{array}{l}\text { No of items/ } \\
\text { questions }\end{array}$ & $\begin{array}{l}\text { Administration mode/ } \\
\text { time }\end{array}$ & Scoring & Validation study & $\begin{array}{l}\text { Language } \\
\text { available }\end{array}$ \\
\hline $\begin{array}{l}\text { NVS (Newest } \\
\text { Vital Signs) }\end{array}$ & $\begin{array}{l}\text { Reading, } \\
\text { comprehension; } \\
\text { numeracy }\end{array}$ & $\begin{array}{l}6 \text { questions on } \\
\text { an ice-cream } \\
\text { nutrition label }\end{array}$ & $\begin{array}{l}\text { Self-administered; } \\
3 \mathrm{~min}\end{array}$ & $\begin{array}{l}\text { Each item } \\
\text { answered } \\
\text { correctly is } \\
\text { given a score of } \\
1 . \text { Scores range: } \\
1-6 \text { (score }<4= \\
\text { limited HL) }\end{array}$ & $\begin{array}{l}\text { (Norrafizah et al. } \\
\text { 2016) }\end{array}$ & Malay \\
\hline $\begin{array}{l}\text { HLS-EU-Q47 } \\
\text { (European } \\
\text { Health } \\
\text { Literacy } \\
\text { uestionnaire) }\end{array}$ & $\begin{array}{l}\text { Prose: } \\
\text { Comprehension, } \\
\text { Information } \\
\text { seeking: } \\
\text { Document, } \\
\text { Application/ } \\
\text { function }\end{array}$ & $\begin{array}{l}47 \text { items across } \\
3 \text { domains } \\
\text { (healthcare, } \\
\text { disease } \\
\text { prevention, } \\
\text { and health } \\
\text { promotion) }\end{array}$ & $\begin{array}{l}\text { Self- or interview } \\
\text { administered; } 15 \mathrm{~min}\end{array}$ & $\begin{array}{l}\text { The } 47 \text { items } \\
\text { are adapted } \\
\text { to a } 50 \text {-point } \\
\text { scale: } 0-25: \\
\text { inadequate } \\
\text { health literacy, } \\
\text { 26-33: } \\
\text { problematic } \\
\text { health literacy, } \\
\text { 33-42: } \\
\text { sufficient } \\
\text { health literacy, } \\
\text { and } 42-50 \text { : } \\
\text { excellent health } \\
\text { literacy }\end{array}$ & $\begin{array}{l}\text { (Duong et al. } \\
\text { 2017) }\end{array}$ & Malay \\
\hline $\begin{array}{l}\text { HLS-SF } 12 \\
\text { (the Health } \\
\text { Literacy } \\
\text { Short-Form } \\
\text { 12) }\end{array}$ & $\begin{array}{l}\text { Prose: } \\
\text { Comprehension, } \\
\text { Information } \\
\text { seeking: } \\
\text { Document, } \\
\text { Application/ } \\
\text { function }\end{array}$ & 12 items & $\begin{array}{l}\text { Self- or interview } \\
\text { administered }\end{array}$ & $\begin{array}{l}\text { The HL } \\
\text { indices were } \\
\text { standardised to } \\
\text { unified metrics } \\
\text { from } 0 \text { to } 50 \text {. } \\
\text { An index } \\
\text { value was } \\
\text { thus obtained } \\
\text { in which } 0 \\
\text { represented the } \\
\text { lowest HL and } \\
50 \text { the highest } \\
\text { HL }\end{array}$ & $\begin{array}{l}\text { (Duong et al. } \\
\text { 2019)024 }\end{array}$ & Malay \\
\hline
\end{tabular}




\begin{tabular}{|c|c|c|c|c|c|}
\hline $\begin{array}{l}\text { Ltems Heal } \\
\text { Literacy in } \\
\text { Dentistry) }\end{array}$ & $\begin{array}{l}\text { Functional oral } \\
\text { health literacy }\end{array}$ & $\begin{array}{l}14 \text { items (seven } \\
\text { conceptual } \\
\text { domains of } \\
\text { HL: access } \\
\text { understanding, } \\
\text { support, } \\
\text { utilisation, } \\
\text { economic } \\
\text { barriers, } \\
\text { receptivity, and } \\
\text { communication) }\end{array}$ & Self-reported; & $\begin{array}{l}\text { Each item } \\
\text { was scored } \\
\text { using a 5-point } \\
\text { Likert scale } \\
\text { ranging from } 1 \\
\text { ("without any } \\
\text { difficulty") to } \\
5 \text { ("Unable to } \\
\text { do"). After re- } \\
\text { coding of } 5 \text { to } \\
0,4 \text { to } 1,3 \text { to } 2 \text {, } \\
2 \text { to } 3 \text {, and } 1 \text { to } \\
4, \text { the possible } \\
\text { range of } \\
\text { summary scores } \\
\text { is from } 0-56 \\
\text { (HeLD-14). } \\
\text { Higher scores } \\
\text { indicate higher } \\
\text { oral health } \\
\text { literacy. }\end{array}$ & $\begin{array}{l}\text { (Muhd Noor et al. } \\
\text { 2019) }\end{array}$ \\
\hline
\end{tabular}

\section{SYNTHESIS OF RESULTS}

The articles were grouped into five important areas of health literacy namely; general health literacy $(n=15)$, medication literacy $(n=4)$, mental health literacy $(n=5)$, media and e-health literacy $(n=3)$ and oral health literacy $(n=4)$. The earliest study (1985) on general health literacy explored patients' perception of disease causation, choice of treatment, preventive measures and food taboo related to infectious disease (Bee 1985). Four studies reported the validation of health literacy tools in a local language, one on NVS, HeLD-14 HLSEU-Q47 and HLS-SF12. (Duong et al. 2017; Norrafizah et al. 2016). The NVS was used the most to measure the level of health literacy in Malaysia. However, the Malay version of NVS was found to be inappropriate and inadequate to measure health literacy among adults in the rural population and its validity among urban adults has not been tested (Norrafizah et al. 2016).

For medication literacy, one study measured the health literacy levels of Malaysian caregivers and parents and tested the influence of their health literacy on the comprehension of medication information and childhood immunisation score (Chan et al. 2015; Nazatul Yusrina et al. 2017). Other studies explored Malaysian consumer's practices, perceptions and understanding regarding the use of acetaminophen and the use of unregistered drugs (Tan et al. 2015; Zulkifli et al. 2016).

Studies on mental health literacy focused on measuring mental health literacy among caregivers, students from the B40 income bracket and university students (Ibrahim et al. 2019; Khan et al. 2010; Mohamad et al. 2012). In one study, psychiatric vignettes were used to examine the mental health literacy of British, Malaysian, and Hong Kong participants (Loo et al. 2012). Another study is a randomised control trial investigating the effectiveness of a 4-week Web-based psychoeducational intervention program for those with depressive and anxiety symptoms in the community of Selangor, Malaysia (Siti Fatimah et al. 2016).

Studies in the last five years concentrated on new areas of health literacy, namely oral health literacy and media and e-health literacy. Given that the field of media and e-health literacy is a fairly new area of health literacy research in Malaysia, studies were focused on the validation of food advertising tool (Zalma et al. 2015) and exploration of media's role on health literacy (Mohamad et al. 2015). A recent study on e-health literacy looked at the search behaviour of students and identified contextual factors affecting health information searching on the Web (Yilma et al. 2019).

Another area of health literacy that is of research interest in Malaysia is on oral health literacy. Research in oral health literacy is catalysed by the availability of validated tools to measure oral health literacy, such as the Malay Health Literacy in Dentistry (HeLD-14) (Muhd Noor et al. 2019). Oral health literacy was measured in children with special needs (Fabillah et al. 2015), and the association between parental oral health literacy and oral health status of preschool children was tested (Ismail et al. 2018). There is also an intervention study looking at the effect of an oral health education program using visual oral health literacy tool on adolescents oral health literacy (Rani et al. 2019).

\section{DISCUSSION}

There were two major findings from this review. First, research on health literacy in Malaysia is limited and second, most published studies focused on general health literacy. Health literacy research done in developing countries trailed behind that of developed countries, 
such as the United States and European countries. In a bibliometric analysis of published papers on health literacy by authors in the European Union from 1991 to 2005, Kondilis et al. (2008) identified 13,710 articles. More articles were published by researchers in the United States, approximately three times the number of articles published in Europe. Developing countries may be focusing on economic development for the improvement of health rather than tackling issues related to health literacy. Since its independence, health reforms in Malaysia focused on restructuring community and eradication of poverty (Sebastian et al. 2016). Health literacy which focuses on patient empowerment and individual attributes, such as knowledge and attitudes are often overlooked. In developing countries where there is rapid economic development, societal resources such as literacy and educational attainment may not have caught up with the expansion in healthcare infrastructure and human resource. Health literacy research needs to be expanded in these countries to adequately deal with this shortfall.

This review identified five main areas of health literacy research in Malaysia. General health literacy was the most studied with fifteen papers published. Five studies used a local language adapted functional health literacy tool, Newest Vital Sign to measure health literacy levels in a variety of populations (Azreena et al. 2016; Chan et al. 2015; Cheong et al. 2018; Norrafizah et al. 2016; Shahrir et al. 2018). Levels of adequate health literacy vary according to the population surveyed; with the highest proportion reported in community-dwelling adults and lowest in caregivers of sick children. As for patients with type 2 diabetes mellitus in primary care, only $14.2 \%$ of Malaysian patients have adequate health literacy compared to $23.7 \%$ in Taiwan (Tseng et al. 2018). There could be many reasons for this observed difference. Critical examinations of health education interventions delivered to patients with type 2 diabetes mellitus in Taiwan compared to Malaysia and comparing the factors associated with lower health literacy levels in these two settings may show some answers. So far, public health researchers have resorted to these small cross-sectional studies to inform them about the burden of limited health literacy in the Malaysian populations.

Health literacy had been measured using different tools in the Asia-Pacific regions, thus making the comparison of health literacy levels across countries difficult. This review identified two studies validating international and regionally used health literacy measurement tools, the HLS-EU-Q47 and HL-SF12. Both validation studies recruited patients from six Asia-Pacific countries (Duong et al. 2019, 2017). The Malay version of the HLS-EU-Q47 was validated in 462 Malaysian and was shown to have good construct validity, satisfactory goodness-of-fit of the data to the hypothetical model in three health literacy domains, high internal consistency (Cronbach's alpha >0.80), satisfactory item-scale convergent validity (item-scale correlation $=0.40$ ), and no floor/ceiling effects. In the same study, Malaysia was found to have the second-highest general health literacy index, 1.5 points behind Taiwan (32.9 vs. 34.4 ) (Duong et al. 2017). The Malay version of the HLS-SF12 index score was $32.7 \pm 7.9$ in Malaysia. The correlation between HL index scores of HLS-SF12 and HLS-EU-Q47 by the Pearson correlation coefficient was satisfactory with a rho-value of 0.96 . The variance of the full form was explained by the HLS-SF12, with $93 \%$ in Malaysia (Duong et al. 2019).

Mental health literacy and medication literacy are two important areas of health literacy research in Malaysia. Mental health literacy is defined as "the knowledge and beliefs about mental disorders, which aids their recognition, management or prevention" (Jorm et al. 1997). Studies included in this review focused more on the assessment of mental health literacy in common mental health conditions, such as anxiety and depression. We identified only one study testing the effectiveness of a web-based psychoeducational intervention program for those with depressive and anxiety symptoms. Future studies should be focusing more on the development of interventions to improve mental health literacy and to include other important mental health conditions, such as schizophrenia. The intervention studies should be carried out by researchers championing mental health literacy in Malaysia.

Lower health literacy scores are associated with patients forgetting to take their medications (Pouliot \& Vaillancourt 2016). Patients with non-communicable diseases in Malaysia were found to have low medication adherence. Studies on medication literacy will be valuable to help tackle this problem. Unfortunately, studies included in this review are limited and have a narrow focus on one drug (i.e. acetaminophen) or one group of drugs only (i.e. unregistered drugs). More studies should be conducted in this area to further our understandings of the role of health literacy in medication adherence in Malaysia.

This review has several limitations. Only three databases were used in this review and given that the MyMedR partly extracts articles from PubMed, there may be duplications. In this review, we wanted to focus on articles dealing with the greater concept of health literacy, which is adequately identified by the review's search term. Quality assessment of the included studies was not done in order to be more inclusive. Future reviews should look into this aspect and may include contacting authors whose work were included in this review to obtain an update of their work in health literacy.

\section{CONCLUSION}

Articles published in the field of health literacy in Malaysia are limited. Future work may be required to build on previous work and to study the challenges faced by these researchers. There are issues with some of the health literacy tools used in recently published 
studies. Therefore, a locally well-validated tool used internationally will enable better measurement of health literacy levels and comparison across countries. There is still much work to be done in the area of health literacy in Malaysia.

\section{ACKNOWLEDGEMENTS}

We thank University Malaya Research Grant (special grant provision No. BKS047-2017) for funding this study and Ms Ranita Hisham Shanmugan, Librarian at the University of Malaya Central Library for her assistance in obtaining full-text articles for the review.

\section{REFERENCES}

Azreena, E., Suriani, I., Juni, M.H. \& Fuziah, P. 2016. Factors associated with health literacy among Type 2 diabetes mellitus patients attending a government health clinic. International Journal of Public Health and Clinical Sciences 3(6): 50-64.

Baker, D.W., Gazmararian, J.A., Williams, M.V., Scott, T., Parker, R.M., Green, D., Ren, J. \& Peel, J. 2002. Functional health literacy and the risk of hospital admission among medicare managed care enrollees. American Journal of Public Health 92(8): 1278-1283

Baker, D.W., Parker, R.M., Williams, M.V. \& Clark, W.S. 1998. Health literacy and the risk of hospital admission. Journal of General Internal Medicine 13: 791-798.

Bee, Y.S. 1985. Health literacy and food beliefs among Ibans, Sarawak. The Medical Journal of Malaysia 40(4): 294-300.

Bennett, C.L., Ferreira, M.R., Davis, T.C., Kaplan, J., Weinberger, M., Kuzel, T., Seday, M.A. \& Sartor, O. 1998. Relation between literacy, race, and stage of presentation among low-income patients with prostate cancer. Journal of Clinical Oncology: Official Journal of the American Society of Clinical Oncology 16(9): 3101-3104.

Chan, H.K., Hassali, M.A., Lim, C.J. \& Saleem, F. 2015. Exploring health literacy and difficulty in comprehending pediatric medication labels among caregivers in Malaysia: A pilot study. Journal of Pharmaceutical Health Services Research 6(3): 165-168.

Cheah, Y.K. \& Su, T.T. 2012. The determinants of consumer health information on chronic non-communicable disease: An exploratory study in Penang, Malaysia. Journal of the University of Malaya Medical Centre 15(2): 1-7.

Cheong Siew Man, Noor Safiza Mohamad Nor, Mohamad Hasnan Ahmad, Mala Manickam, Rashidah Ambak, Siti Nurbaya Shahrir. \& Tahir Aris. 2018. Improvement of health literacy and intervention measurements among low socioeconomic status women: Findings from the MyBFF@home study. BMC Women's Health 18(1): 99.

Chuen, E.M., Michael, E. \& Teh, B.T. 2016. The role of media socialization agents in increasing obesity health literacy among Malaysian youth. Jurnal Komunikasi: Malaysian Journal of Communication 32(2): 691-714.

Duong, T.V., Aringazina, A., Kayupova, G., Nurjanah, Pham, T.V., Pham, K.M., Truong, T.Q., Nguyen, K.T., Oo, W.M., Su, T.T., Hazreen Abdul Majid, Sørensen, K., Lin, I.F., Chang, Y., Yang, S-H. \& Chang, P.W.S. 2019. Development and validation of a new short-form Health Literacy Instrument (HLS-SF12) for the general public in six Asian countries. Health Literacy Research and Practice 3(2): e91-e102.

Duong, T.V., Aringazina, A., Baisunova, G., Nurjanah, Pham,
T.V., Pham, K.M., Truong, T.Q., Nguyen, K.T., Oo, W.M., Emma Mohamad, Su, T.T., Huang, H-L., Sørensen, K., Pelikan, J.M., Van den Broucke, S. \& Chang, P.W.S. 2017. Measuring health literacy in Asia: Validation of the HLSEU-Q47 survey tool in six Asian countries. Journal of Epidemiology 27(2): 80-86.

Fabillah, N.S.A., Mustapa, N., Rohani, M.M. \& Esa, R. 2015. Oral health literacy among carers of special needs children in Kuala Terengganu, Malaysia. Annals of Dentistry 22(1): 15-20.

Froze, S., Arif, M.T. \& Saimon, R. 2019. Determinants of health literacy and healthy lifestyle against metabolic syndrome among major ethnic groups of Sarawak, Malaysia: A multigroup path analysis. Open Public Health Journal 12(1): 172-183. https://doi.org/10.2174/1874944501912010172.

Gordon, M.M., Hampson, R., Capell, H.A. \& Madhok, R. 2002. Illiteracy in rheumatoid arthritis patients as determined by the Rapid Estimate of Adult Literacy in Medicine (REALM) Score. Rheumatology 41(7): 750-754

Hagger, M.S., Hardcastle, S.J., Hu, M., Kwok, S., Lin, J., Nawawi, H.M., Pang, J., Santos, R.D., Soran, H., Su, T-C., Tomlinson, B. \& Watts, G.F. 2018. Health Literacy in familial hypercholesterolemia: A cross-national study. European Journal of Preventive Cardiology 25(9): 936-943. https:// doi.org/10.1177/2047487318766954.

Hamzah, M.R., Mohamad, E. \& Abdullah, M.Y. 2016. Influence of health literacy on health information seeking behavior among students in public university. Jurnal Komunikasi: Malaysian Journal of Communication 32(2): 405-424.

Hamzah, S.R., Ismail, M. \& Mohd Nor, Z. 2018. Does attachment to parents and peers influence health literacy among adolescents in Malaysia? Kontakt 20(4): e348-e355. https://doi.org/10.1016/j.kontakt.2018.10.006.

Heijmans, M., Uiters, E., Rose, T., ter Hofstede, J., Devillé, W., van der Heide, I., Boshuizen, H.C. \& Rademakers, J. 2014 Study on sound evidence for a better understanding of health literacy in the European Union: Final Report. Luxembourg. https://doi.org/10.2818/150402.

Howard, D.H., Gazmararian, J. \& Parker, R.M. 2005. The impact of low health literacy on the medical costs of medicare managed care enrollees. The American Journal of Medicine 118(4): 371-377.

Ibrahim, N., Amit, N., Shahar, S., Wee, L.H., Ismail, R., Khairuddin, R., Siau, C.S. \& Mohd Safien, A. 2019. Do depression literacy, mental illness beliefs and stigma influence mental health help-seeking attitude? A crosssectional study of secondary school and university students from B40 households in Malaysia. BMC Public Health 19(4): 544

Institute for Public Health (IPH). 2015. National Health and Morbidity Survey 2015 (NHMS 2015). Volume II: NonCommunicable Diseases, Risk Factors \& Other Health Problems.

Ismail, A.F., Ardini, Y.D., Mohamad, N. \& Bakar, H.A. 2018. Association between parental oral health literacy and children's oral health status. Revista Latinoamericana de Hipertension 13(3): 305-309.

Jorm, A.F., Korten, A.E., Jacomb, P.A., Christensen, H., Rodgers, B. \& Pollitt, P. 1997. Mental health literacy': A survey of the public's ability to recognise mental disorders and their beliefs about the effectiveness of treatment. The Medical Journal of Australia 166(4): 182-186.

Kalichman, S.C., Benotsch, E., Suarez, T., Catz, S., Miller, 
J. \& Rompa, D. 2000. Health literacy and health-related knowledge among persons living with HIV/AIDS. American Journal of Preventive Medicine 18(4): 325-331.

Kalichman, S.C. \& Rompa, D. 2000. Functional health literacy is associated with health status and health-related knowledge in people living with HIV-AIDS. Journal of Acquired Immune Deficiency Syndromes 25(4): 337-344.

Khan, T.M., Sulaiman, S.A. \& Hassali, M.A. 2010. Mental health literacy towards depression among non-medical students at a Malaysian University. Mental Health in Family Medicine 7(1): 27-35.

Kondilis, B.K., Kiriaze, I.J., Athanasoulia, A.P. \& Falagas, M.E. 2008. Mapping health literacy research in the European Union: A bibliometric analysis. PLoS ONE 3(6): e2519.

Loo, P.W., Wong, S. \& Furnham, A. 2012. Mental health literacy: A cross-cultural study from Britain, Hong Kong and Malaysia. Asia-Pacific Psychiatry 4(2): 113-125.

Mohamad, E., Haniff, N.A.M., Salleh, S.M., Ahmad, A.L. \& Hashim, H. 2015. Health and media literacy: The choice of milk amongst mothers for the growth of children. Jurnal Komunikasi: Malaysian Journal of Communication 31(2): 83-97.

Mohamad, S., Zabidah, P., Fauziah, I. \& Sarnon, N. 2012. Mental health literacy among family caregivers of schizophrenia patients. Asian Social Science 8(9): 74-82.

Muhd Noor, N., Rani, H., Zakaria, A.S.I., Yahya, N.A. \& Sockalingam, S.N. 2019. Sociodemography, oral health status and behaviours related to oral health literacy. Pesquisa Brasileira Em Odontopediatria e Clinica Integrada 19(1): https://doi.org/10.4034/PBOCI.2019.191.120.

Nazatul Yusrina Mohamad Yusof, Nor Afiah Mohd Zulkefli, Suriani Ismail. \& Mohammad Faid Abd Rashid. 2017. Inadequate health literacy on childhood immunization and its predictors among antenatal mothers. Malaysian Journal of Medicine and Health Sciences 13(3): 51-59.

Nielsen-bohlman, L., Panzer, A.M. \& Kindig, D.A. 2004. Health Literacy: A Prescription to End Confusion. Washington: The National Academic Press.

Norrafizah, J., Nor Asiah, M., Suraiya, S.M., Zawaha, H.I. \& Normawati, A. 2016. Assessment of health literacy among people in a rural area in Malaysia using newest vital signs assessment. Journal of Education, Society and Behavioural Science 16(2): 1-7.

Pouliot, A. \& Vaillancourt, R. 2016. Medication literacy: Why pharmacists should pay attention. Canadian Journal of Hospital Pharmacy 69(4): 335-336.

Rani, H., Su, M.Y.H., Ding, A.D.A., Yahya, N.A. \& Jaafar, A. 2019. Comparison of visual oral health literacy level pre and post oral health education among adolescents. Journal of International Dental and Medical Research 12(2): 640-644.

Schillinger, D., Piette, J., Grumbach, K., Wang, F., Wilson, C., Daher, C., Leong-grotz, K., Castro, C. \& Bindman, A.B. 2003. Closing the loop: Physician communication with diabetic patients who have low health literacy. Archives of Internal Medicine 163(13): 83-90.

Schillinger, D., Grumbach, K., Piette, J. \& Al, E. 2002. Association of health literacy with diabetes outcomes. JAMA: The Journal of the American Medical Association 288(4): 475-482.

Scott, T.L., Gazmararian, J.A., Williams, M.V. \& Baker, D.W. 2002. Health literacy and preventive health care use among medicare enrollees in a managed care organization. Medical Care 40(5): 395-404.
Sebastian, A., Mohamed Ali Alzain, Asweto, C.O., Mahara, G., Guo, X.H., Song, M., Wang, Y.X. \& Wang, W. 2016. The Malaysian health care system: Ecology, plans, and reforms. Family Medicine and Community Health 4(3): 19-29.

Shahrir, S.N., Shamsuddin, K., Mohamad Nor, N.S., Man, C.S., Omar, M.A., Ahmad, M.H. \& Ambak, R. 2018. Limited health literacy and its associated factors among overweight and obese housewives living in Klang Valley low cost flats: Findings from the my body is fit and fabulous at home (Mybff@Home) study. Malaysian Journal of Public Health Medicine 18(1): 19-27.

Shaw, S.J., Huebner, C., Armin, J., Orzech, K. \& Vivian, J. 2009. The role of culture in health literacy and chronic disease screening and management. J. Immigrant Minority Health 11(6): 460-467.

Skau, J.K.H., Awatef, A.N., Cheah, J.C.H., Roslinah, A., Ramli, Z., Tahir, A., Zainudin M.A., Priya, M., Regien, B., AagaardHansen, J., Hanson, M.A. \& Norries, S.A. 2016. A complex behavioural change intervention to reduce the risk of diabetes and prediabetes in the pre-conception period in Malaysia: Study protocol for a randomised controlled trial. Trials 17: 215. https://doi.org/10.1186/s13063-016-1345-x.

Siti Fatimah Kader Maideen, Sherina Mohd-Sidik, Lekhraj Rampal, Firdaus Mukhtar, Normala Ibrahim, Cheng-Kar Phang., Kit-Aun Tan. \& Rozali Ahmad. 2016. A web-based psychoeducational intervention program for depression and anxiety in an adult community in Selangor, Malaysia: Protocol of a randomized controlled trial. JMIR Research Protocols 5(2): e112.

Tan, S.F., Chong, C.P. \& Chooi, W.T. 2015. An evaluation of practices, perceptions and understanding about use of acetaminophen (paracetamol) among Malaysian consumers: A qualitative study. Malaysian Journal of Pharmaceutical Science 13(1): 25-41. http://mymedr.afpm. org.my/publications/46167.

Tseng, H-M., Liao, S-F., Wen, Y.P. \& Chuang, Y.J. 2018. Adaptation and validation of a measure of health literacy in Taiwan: The newest vital sign. Biomedical Journal 41(4): 273-278.

Williams, M.V., Baker, D.W., Honig, E.G., Lee, T.M. \& Nowlan, A. 1998a. Inadequate literacy is a barrier to asthma knowledge and self-care. CHEST 114(4): 1008-1015.

Williams, M.V., Baker, D.W., Parker, R.M. \& Nurss, J.R. 1998b. Relationship of functional health literacy to patients' knowledge of their chronic disease: A study of patients with hypertension and diabetes. Archives of Internal Medicine 158(2): 166-172.

World Health Organization. 2017. Shanghai declaration on promoting health in the 2030 agenda for sustainable development.

Yilma, T.M., Inthiran, A., Reidpath, D.D. \& Orimaye, S.O. 2019. Context-based interactive health information searching. Information Research 24(2): 1-22.

Zalma, A.R., Safiah, M.Y., Ajau, D. \& Khairil Anuar, M.I. 2015. Reliability and validity of television food advertising questionnaire in Malaysia. Health Promotion International 30(3): 523-530.

Zulkifli, N.W., Aziz, N.A., Hassan, Y., Hassali, M.A. \& Bahrin, N.L.Z. 2016. Do current awareness and educational program towards unregistered drugs effective for public? Pharmacists' perceptive. International Journal of Pharmacy and Pharmaceutical Sciences 8(7): 81-85. 
Adina Abdullah, Liew Su May* \& Ng Chirk Jenn

Department of Primary Care Medicine

University Malaya Primary Care Research Group (UMPCRG)

Faculty of Medicine

University of Malaya

50603 Kuala Lumpur, Federal Territory

Malaysia

Hani Syahida Salim

Department of Family Medicine

Faculty of Medicine and Health Science

Universiti Putra Malaysia

43400 UPM Serdang, Selangor Darul Ehsan

Malaysia
Karuthan Chinna

School of Medicine

Faculty of Health and Medical Sciences

Taylor's University, Kuala Lumpur, Federal Territory

Malaysia

*Corresponding author; email: su_mayliew@um.edu.my

Received: 5 April 2019

Accepted: 15 January 2020 